О. М. Цимбал // Права людини - громадянська освіта: Бюлетень Харківської правозах. Групи. - 2006. - №18 (418). - С. 4-6. 6. Цимбал О. М. Проектна технологія, критичне мислення і громадянська освіта в процесі вивчення англійської мови. Початкова школа / О. М. Цимбал, О. В. Тягло, П. В. Цимбал. - Х. : Вид. група «Основа», 2008. - 109, (3) с. (Б-ка журн. «Англійська мова та література»; Вип. 4 (64)).

\title{
ПРОФЕСІЙНИЙ РОЗВИТОК УЧИТЕЛЯ ПОЧАТКОВИХ КЛАСІВ У ПЕРІОД УВЕДЕННЯ У ПРОФЕСІЮ У РОСІЙСЬКІЙ ФЕДЕРАЦІЇ
}

Поперечна Л. Ю. Професійний розвиток учителя початкових класів у період введення у професію у Російській Федерації.

Дослідження присвячене актуальній темі- професійному розвитку учителя початкових класів у період уведення у професію. У статті представлено модель організаційно-педагогічного забезпечення професійного становлення вчителя початкових класів. Автором досліджено напрями управління професійним розвитком учителя, проаналізовано етапи входження молодого вчителя у професію.

Ключові слова: професійний розвиток учителя початкових класів, становлення, модель, напрями, етапи професійного розвитку.

Поперечная Л. Ю. Профессиональное развитие учителя начальных классов в период введения в профессию в Российской Федерации.

Исследование посвящено актуальной теме - профессиональному развитию учителя начальных классов в период введения в профессию. В статье представлена модель организационно-педагогического обеспечения профессионального становления учителя начальных классов. Автором исследованы пути управления профессиональным развитием учителя, проанализированы этапы вхождения молодого учителя в профессию.

Ключевые слова: профессиональное развитие учителя начальных классов, становление, модель, направления, этапы профессионального развития.

Poperechna L. U. Teacher's professional development of primary classes during the introduction to the profession.

Survey was devoted to the actual topic, teacher's professional development of primary classes in the period of introduction to the profession. The article presents a model of the organizational-pedagogical support the professional development of teacher of primary classes. The author explored the ways of managing professional development of teachers, analyzed the stages of entering of young teachers in the profession.

Key words: professional development for primary teachers, formation, model, directions, stages of professional development.

Проблема професійного розвитку вчителя, його світоглядної культури, духовноморального обличчя - одна 3 найактуальніших у педагогіці й філософії освіти, адже саме від педагога, його особистісних характеристик залежить якість освітніх послуг, виховання учнів як під час реалізації навчальних програм, так і в позанавчальний час. У Національній доктрині розвитку освіти України у XXI столітті, у Державній програмі «Вчитель» наголошено на необхідності формування особистості вчителя відповідно до 
потреб сучасної практики, динамічних змін, що відбуваються в країні, світі. Зрозуміло, цей процес потребує теоретичного забезпечення. Тому дослідження проблеми формування особистості сучасного вчителя, його професійного розвитку, зокрема в період уведення у професію, є актуальним.

Проблему професійного становлення молодих спеціалістів, зокрема вчителя початкових класів, дослідники розглядають 3 погляду професійної підготовки (О. Абдуліна, В. Сластьонін), професійно-особистісного зростання (С. Вершловський, Л. Лєсохіна, В. Моргун, Н. Ткачов), безперервної професійної освіти (Н. Данілов, В. Ігнатьєв, Т. Кисельова, Л. Коновалова, Є. Михайлова, Н. Неустроєв, Т. Саввінов, Р. Тимофєєва, О. Торосова); методологічні та теоретичні дослідження, спрямовані на удосконалення навчально-виховного процесу у ВНЗ (А. Алексюк, І. Бех, О. Бігич, В. Бондар, М. Бурда, В. Гриньова, С. Гончаренко, О. Глузман, М. Євтух, О. Дубасенюк, Н. Кузьміна, В. Лозова, Н. Ничкало, С. Сисоєва, Г. Тарасенко, Л. Хомич, Л. Хоружа, М. Чобітько). Науковець Л. Анциферова вважає, що під час професійного становлення відбувається розширення й збагачення всієї системи життєвих стосунків людини. Міркуючи про співвідношення особистості та діяльності, Л. Анциферова стверджує, що «...професійна діяльність забезпечує повноцінний розвиток здібностей лише тією мірою, наскільки в ній відбувається розвиток цілісної особистості та іiі пересування на новий рівень соціального буття. У міру оволодіння професією відбувається ідентифікація особистості зі своєю діяльністю» [2, с. 13]. Отже, можемо стверджувати, що людина стає особистістю лише в розвитку ії як суб'єкта діяльності.

Метою статті є дослідження питань ефективного професійного розвитку вчителя початкових класів у період уведення у професію.

Професійне становлення молодих спеціалістів-безперервний процес набуття особистістю професійної компетентності, яка виражається в саморозвитку та самореалізації в педагогічній діяльності [1, с. 48].

Професійний розвиток педагогів-початківців сприяє досягненню оптимального співвідношення між комплексом вимог до професії вчителя загалом та їх реалізацією в педагогічній діяльності професіоналів-початківців в умовах освітнього простору. Це процес, що передбачає професійну соціалізацію особистості через потребу в самореалізації та самоосвіті.

У період уведення у професію в учителя-початківця закладаються основи його неперервного професійного розвитку та підвищення кваліфікації. Учитель-початківець має змогу продемонструвати власний потенціал, усвідомити важливість професійного розвитку та здійснення впливу на удосконалення шкільної освіти.

Метою періоду введення у професію є забезпечення цільового моніторингу та підтримки учителя-початківця загальноосвітньої школи, зокрема вчителя початкових класів, а також підвищення його кваліфікації впродовж першого року професійної діяльності.

Становлення - це цілеспрямований професійний розвиток учителя. Найважливішими компонентами професійного становлення вчителя початкових класів дослідники визначають: соціально-психологічну адаптацію, формування професійної свідомості, самоствердження у професії, опанування педагогічною діяльністю і рольовою поведінкою, опанування морально-педагогічним досвідом соціального середовища.

Під час вивчення професійного становлення молодих спеціалістів в умовах школи провідний спеціаліст у галузі педагогіки Російської Федерації І. Федотенко визначила системний, компетентнісний та особистісно зорієнтований підходи, які сприяють розвитку професійно-особистісних рис, професійної активності, творчої самореалізації [6, с. 19]. Так, професійне становлення молодих спеціалістів 3 позиції 
системного підходу автор розглядає як системну організацію їхньої діяльності; компетентнісний підхід передбачає створення умов для сприятливого входження педагогів у професію завдяки діяльності методичних служб та суспільних об'єднань ветеранів педагогічної праці; особистісно зорієнтована стратегія професійного розвитку молодих спеціалістів дозволяє індивідуалізувати педагогічний супровід, спрямований на розкриття, реалізацію внутрішнього потенціалу, саморозвиток i самореалізацію педагогів-початківців через використання особистісно- i практико-орієнтованих технологій підвищення їхньої кваліфікації.

Ефективності професійного становлення вчителя-початківця сприяють: забезпечення безперервності цього процесу в системі: школа-методична службасуспільні об'єднання ветеранів педагогічної праці; здійснення співпраці молодих учителів та ветеранів педагогічної праці, яка передбачає суб'єкт-суб'єктну взаємодію, діалоговий обмін досвідом; реалізація особистісно-орієнтованої спрямованості підвищення кваліфікації молодого спеціаліста.

Ураховуючи особливості процесу професійного розвитку педагога-початківця, зокрема вчителя початкових класів, І. Алексєєвою розроблено теоретичну модель організаційно-педагогічного забезпечення професійного становлення молодих спеціалістів [1, с. 11-13]. Ця модель передбачає систему взаємопов'язаних структурнофункціональних блоків (підсистем), які складаються із сукупності елементів: цільового (мета, принципи, задачі), змістового, управлінського (педагогічні умови, етапи, форми та методи підвищення кваліфікації), оцінно-результативного.

Цільова підсистема зорієнтована на максимальний особистісний та професійний розвиток педагога-початківця. Принципами управління професійним становленням молодого спеціаліста $\epsilon$ такі: гуманістична спрямованість освіти, яка передбачає створення сприятливих умов для розкриття особистісних та професійних можливостей молодого педагога; цілісність, яка забезпечує єдність та взаємозв'язок підсистем моделі, ii компонентів; безперервність, яка сприяє якісним перетворенням професійної діяльності молодого спеціаліста.

Функціями змістової підсистеми є такі: освітня, інформаційна, консультативна, дослідницька, експертна, організаційна тощо.

Основні напрями управління професійним становленням молодого спеціаліста: створення методичної служби задля сприяння професійного розвитку педагогів, формування, розвитку та раціонального використання професійного потенціалу кожного вчителя, забезпечення можливостей самореалізації молодого спеціаліста, організації і передачі досвіду вчителя-наставника.

Управлінська підсистема реалізує взаємопов'язані та взаємозумовлені етапи: адаптаційний, процесуальний, результативний; передбачає колективні (педагогічні ради, огляди-конкурси, науково-практичні конференції, лекторії, круглі столи), групові (проблемні семінари, ділові ігри, методичні поради, суспільні об'єднання молодих педагогів) та індивідуальні (творчі майстерні, наставництво, консультації, спільні новаторські проекти) особистісні та практико-орієнтовані форми та методи підвищення кваліфікації молодих педагогів.

Оцінно-результативна підсистема охоплює критеріально-оціночний апарат дослідження, який дозволяє визначити рівні (низький, середній, високий) професійного становлення молодих спеціалістів.

Важливим джерелом для визначення напрямів професійного розвитку вчителя початкових класів у системі неперервної педагогічної освіти в Україні $\epsilon$ вивчення та аналіз практики вчителя-початківця в системі неперервної педагогічної освіти Російської Федерації. 
Варто зауважити, що період уведення в професію у Російській Федерації $\epsilon$ необхідною умовою для отримання посади вчителя загальноосвітньої школи, а наставництво визначають як один 3 обов'язків досвідченого вчителя. Моніторинг та підтримка професійного становлення молодого вчителя передбачає надання допомоги й управління процесом уведення в професію досвідченим педагогом; спостереження та обговорення проведених уроків; професійний аналіз прогресу вчителя-початківця; спостереження та аналіз уроків, проведених досвідченими вчителями; інші види діяльності, спрямовані на професійний розвиток учителя-початківця.

Так, за 2010-2012 роки в Росії організовано низку заходів, спрямованих на професійний розвиток педагогічних кадрів: Всеросійські професійні конкурси («Учитель року Росії», «Виховувати людину», «Серце віддаю дітям»), IV Міжнародний конгрес «Освіта без кордонів», Всеросійський телевізійний конкурс «ТЕФІ-Регіон», Всеросійський конкурс у мережі Інтернет «Премія Рунету-2010», учасниками яких були і молоді вчителі початкових класів.

Проаналізуємо основні етапи входження молодого вчителя початкових класів у професію.

Перший етап - практичний, підготовчий. Учитель-початківець найчастіше не має особистісного ставлення до виконуваних дій. Для нього характерний симбіоз із іншими, наприклад, авторитетним педагогом, викладачем ВНЗ, відомим учителем-новатором. Знання педагога абстрактні, віддалені від практики. Особистісна та професійна незрілість - загальна особливість педагогів, які перебувають на цьому етапі становлення.

Робота з учителем на початковому етапі відбувається насамперед у визначенні мотивів професійної діяльності та їх оцінці. Вивчаються межі й ресурси як професійної компетентності, так і особистісних можливостей (емоційної стійкості, терпимості). 3 боку керівника відбувається транслювання відповідальності як основи професійного розвитку. Організовується спостереження за роботою досвідченого фахівцяпрофесіонала за запропонованою схемою, що дозволяє розрізняти та класифікувати те, що спостерігається, а також створювати індивідуальну систему (картотека, словник, банк) освоєння методичних прийомів. Молодий спеціаліст усвідомлює та осмислює способи проведення занять та бесід з учнями.

Другий етап - початковий рівень професійної роботи. У педагога актуалізуються особистісні та професійні проблеми. Учитель активно копіює вміння авторитетних колег і тиражує власні випадкові знахідки. Форми роботи з педагогом на цьому етапі становлення передбачають докладний аналіз професійних спроб. Професійні й особистісні досягнення цього періоду передбачають формуванню готовності вчителя до самостійної роботи. Відбувається поступове створення індивідуального банку засвоєних i застосовуваних методичних прийомів, формулюється власне розуміння змісту призначення роботи.

Третій етап - професійно-унормований рівень. Учитель виявляє задоволеність належністю до професійної групи, він відповідально ставиться до загальної педагогічної справи. У тих педагогів, які продовжують працювати, відбувається розподіл особистісного та професійного. Форми роботи з молодим фахівцем спрямовані на аналіз навчальної взаємодії з учнями. Розробляються та впроваджуються нові форми роботи. Професійні й особистісні досягнення фахівця, який знаходиться на цьому етапі становлення, підтверджують професійну зрілість працівника школи.

Четвертий етап- рівень гуманістичної роботи. На цьому етапі відбувається продукування індивідуальних форм освітньої підтримки у взаємодії з учнями. Форми роботи 3 педагогами спрямовані на активне ділове обговорення реальних випадків 3 практики, що дозволяє адекватно оцінювати дії іншого та підтримувати професійну 
форму. Активізується діяльність та спілкування із професійним співтовариством (участь у семінарах, конференціях, курсах підвищення кваліфікації тощо). Професійні й особистісні досягнення педагога цього рівня розвитку визначаються мовною формулою «стійка гуманістична професійна позиція». У вчителя сформоване диференційоване узагальнене уявлення про себе як особистість і як професіонала. Він чітко усвідомлює межі своєї компетентності та відповідальності. Виявляє високу готовність до підвищення самоосвітнього рівня.

На п’ятому етапі професійного розвитку відбувається синтез у єдину категорію «людина-педагог». Особистісна цілісність і автентичність виявляються в активності професійної діяльності, а як продовження - у системній самоосвітній діяльності. Форми роботи $з$ подальшого професійного розвитку вчитель вибирає для себе сам. Серед близьких йому за духом професіоналів формується цінність підтримки постійних зв'язків із зовнішнім середовищем.

Отже, вчитель-початківець загальноосвітньої школи демонструє особисті професійні якості, знання й усвідомлює професійні навички та вміння на кожному етапі його професійного становлення. Місцеві органи управління освітою Російської Федерації забезпечують можливості для активної участі вчителя початкових класів у семінарах, конференціях, програмах професійного розвитку. Так, у Федеральній цільовій програмі розвитку освіти на 2011-2015 роки вказано: «Держава розглядає поліпшення матеріального становища та підвищення соціального статусу працівників освіти як одне з пріоритетних завдань освітньої політики... Уведення надбавок молодим спеціалістам на перші три роки педагогічної діяльності, надбавок за тривалість безперервної роботи в освітніх установах, а також надбавок, що стимулюють високі результати педагогічної діяльності» [7, с. 5]. Учитель початкових класів усвідомлює професійні обов'язки та важливість обраної ними професії. На індивідуальному рівні педагог оволодіває інформаційно-комунікаційними технологіями, розвиває особисті професійні якості. На рівні загальноосвітньої школи переймає досвід колег, бере активну участь у шкільних методичних об'єднаннях, залучає до спільних загальношкільних справ, участі у фестивалі педагогічних ідей «Відкритий урок», а тому і професійно розвивається.

Щодо національної системи підтримки молодого спеціаліста в період уведення у професію, то вона $є$ малорозробленою, на державному рівні не підтримується належним чином, зокрема фінансово. Статус учителя під час періоду введення у професію знаходиться на низькому рівні. Учитель початкових класів усвідомлює значущість професії, долучається до дослідницької та методичної роботи у школі, пристосовується до нововведень у педагогічній діяльності, планує особистий професійний розвиток згідно 3 національними стандартами, співпрацює 3 учителями вищої категорії та переймає кращі приклади практики школи.

Аналіз професійного розвитку вчителя початкових класів у період уведення у професію у Російській Федерації дозволяє зробити загальний висновок про необхідність об'єктивного та вдумливого врахування здобутків Російської Федерації в галузі освіти та модернізацію організації професійного розвитку вчителя початкових класів в Україні, зокрема у період уведення у професію.

Перспективи подалыших пошуків убачаємо у висвітленні питань, пов'язаних 3 професійним розвитком учителя початкової школи, що $є$ особливо актуальним на сучасному етапі розвитку професійної освіти в Україні. 


\section{Література}

1. Алексеева И. С. Профессиональное становление молодых специалистов в условиях сельской школы: автореф. дис. на соискание ученой степени канд. пед. наук : спец. : 13.00.01 - «Общая педагогика, история педагогики и образования» / Ирина Степановна Алексеева. - Якутск, 2006. - 21 с. 2. Анцыферова Л. И. Психология личности как развивающейся системы / Л. И. Анцыферова // Психология формирования и развития личности. - М. : Наука, 1991. - 238 с. 3. Закон України «Про освіту» від 23 травня 1991 року. [Електронний ресурс]. - Режим доступу: osvita.ua. 4. Національна доктрина розвитку освіти України у XXI столітті. [Електронний ресурс]. - Режим доступу: http://www.gdo.kiev.ua. 5. Маркова А. К. Психология профессионализма / А. К. Маркова - М. : Знание. - 1996. - 308 с. 6. Федотенко И. Л. Молодой учитель и его старшие коллеги: два взгляда на одну проблему // Директор школы. - 1997. - № 4. С. 18-24. 7. Федеральная целевая программа развития образования на 2011-2015 годы. [Електронний ресурс].- Режим доступу: http://www.garant.ru/products/ipo/prime/doc/ $55070647 /$.

УДК 37.036:371.13:78.01

Лариса Серих

\section{ГУМАННІ ВЗАЄМИНИ ЯК БАЗОВИЙ КОМПОНЕНТ ЗМІСТУ ФОРМУВАННЯ ЕСТЕТИЧНОГО СЕРЕДОВИЩА УЧНІВ ОСНОВНОї ТА СТАРШОЇ ШКОЛИ}

Сєрих Л. В. Гуманні взаємини як базовий компонент змісту формування естетичного середовища учнів основної та старшої школи

У статті розкрито результати експерименту відповідно до теми дослідження. Визначено ступінь здатності учнів до естетичної діяльності та ступінь розуміння естетичної цінності навколишнього світу, вияв інтересу до мистецтва, створення гуманних взаємини. Розглянуто сутність гуманних взаємовідносин учнів основної та старшої школи i показано вплив таких стосунків на формування естетичного середовища старшокласників.

Ключові слова: гуманні взаємини, естетичне середовище, вчительекспериментатор, учні основної та старшої школи, естетична діяльність.

Серых Л. В. Гуманные взаимоотношения как базовый компонент содержания формирования эстетической среды учащихся основной и старшей школы.

В статье раскрыты результаты эксперимента в соответствии темы исследования. Определена степень способности учащихся к эстетической деятельности и степень понимания эстетической ценности окружающего мира, проявление интереса к искусству, создания гуманных взаимоотношений. Рассмотрена сущность гуманных взаимоотношений учеников основной и старшей школы, показано влияние данных отношений на формирование эстетического среды старшеклассников.

Ключевые слова: гуманные взаимоотношения, эстетическая среда, учительэкспериментатор, учащиеся основной и старшей школы, эстетическая деятельность.

Sierykh L. V. Humane relationships as a basic component of the content of forming aesthetic environment of pupils primary and high school.

The article deals with the results of the experiment under the topic of the research. The degree of ability of pupils to the aesthetic activity and the degree of understanding of the aesthetic values of the surrounding world, the manifestation of interest in the art determined, 